\title{
Prognostic significance and clinical importance of estrogen receptor $\alpha$ and $B$ in human endometrioid adenocarcinomas
}

\author{
IOANNIS MYLONAS \\ First Department of Obstetrics and Gynecology, Ludwig-Maximilians-University Munich, \\ Maistrasse 11, D-80337, Munich, Germany
}

Received January 19, 2010; Accepted April 13, 2010

DOI: $10.3892 /$ or_00000871

\begin{abstract}
Human endometrial cancer expresses both the known estrogen receptors (ER- $\alpha$ and ER- $\beta$ ). The significance of the relative expression of both ER subtypes in endometrial adenocarcinomas remains to be clarified and the usefulness of the determination of the receptor status in endometrial cancer patients is still controversially discussed. Therefore, the aims of this study were the evaluation of the expression patterns of ER- $\alpha$ and ER- $\beta$ with the characterization of the prognostic significance in uterine endometrioid adenocarcinomas. Pathological and surgical records of 214 patients who were diagnosed with an endometrioid adenocarcinoma without other histological types (including mucinous, mixed, squamous or villoglandular differentiation) were reviewed for both estrogen receptors. The expression of both estrogen receptors was demonstrated in malignant endometrioid adenocarcinomas. ER- $\alpha$ was associated with histological differentiation, while ER- $\beta$ demonstrated an association with ovarial invasion. The loss of receptor positivity for ER- $\alpha$ resulted in a poorer causespecific survival in endometrial cancer patients, while ER- $\beta$ did not affect survival. Interestingly, metastatic patients who expressed ER- $\alpha$ or ER- $\beta$ had a better survival outcome than estrogen receptor negative patients. Moreover, when tumor samples of affected patients expressed ER- $\alpha$, they had a better cause-specific survival compared to negative findings regarding both estrogen receptors. However, ER- $\alpha$ and ER- $\beta$ were not independent factors with survival in endometrial adenocarcinoma patients. Therefore, the analysis of both estrogen receptors might be used as a marker to identify highrisk patients only in a subset of patients with endometrioid adenocarcinoma.
\end{abstract}

Correspondence to: Dr Ioannis Mylonas, First Department of Obstetrics and Gynecology, Ludwig-Maximilians-University Munich, Maistrasse 11, D-80337 Munich, Germany

E-mail: ioannis.mylonas@med.uni-muenchen.de

Key words: endometrium, cancer, adenocarcinomas, immunohistochemistry, estrogen receptor $\alpha$, estrogen receptor $\beta$, survival

\section{Introduction}

Endometrial cancer has become the most frequent gynecologic malignancy in the Western world (1-6). An incidence of 15-20 to 100,000 women per year has been estimated with a life time risk to develop this type of cancer being approximately $2.5 \%$ (7). Meanwhile, several prognostic factors such as histological type, histological grade, surgical stage, pelvic lymph node involvement and myometrial invasion being established (1-6). Therefore, the International Federation of Gynecology and Obstetrics (FIGO) has established a surgical staging system for endometrial cancer, including an explorative laparotomy with radical hysterectomy and bilateral salpingo-oophorectomy, peritoneal washing and a pelvic and para-aortic lymph node dissection (8).

Meanwhile, endometrial cancer has been described as consisting of two distinct groups with different biological and molecular characteristics $(9,10)$. Endometrioid adenocarcinomas are the most common histopathological form and belong to the group I endometrial cancers with a more favourable outcome compared to endometrial cancer of the second group $(6,9,10)$. The carcinogenesis of endometrioid adenocarcinomas is predominantly thought to be due to an excess estrogen exposure or conditions resulting in unopposed estrogens (1-6). The cellular action of estrogen is mediated through the estrogen receptors (ER) that belong to the nuclear steroid receptor superfamily (11-13). Meanwhile, two distinct ERs, defined as ER- $\alpha$ and ER- $\beta$, have been identified $(11,12)$. In the human uterus, ER- $\alpha$ is the predominant subtype (14) and it is believed to be an independent prognostic factor in women with endometrial carcinoma $(3,15,16)$. However, ER-ß might play an important role by modulating ER- $\alpha$ function as demonstrated in an ER- $\alpha$ knockout model (17). The loss of ER- $\beta$ expression in cancer cells might be a characteristic step in tumor cell dedifferentiation (13). Moreover, an imbalance in the ER- $\alpha$ and ER- $\beta$ expression might be of substantial importance in estrogendependent carcinogenesis $(13,14,18-20)$.

The significance of the relative expression of both ER subtypes in endometrial adenocarcinomas remains to be clarified and the usefulness of the determination of the receptor status in endometrial cancer patients is still controversially discussed (21). Interestingly, since no association with the 
ER- $\beta$ expression and clinicopathological characteristics could be observed in endometrial cancer $(22,23)$, it seems that ER- $\beta$ analysis might be only useful if evaluated with ER- $\alpha$ as a ratio $(13,14,18,22,23)$.

Therefore, the aims of this study were the re-evaluation of the expression patterns of ER- $\alpha$ and ER- $\beta$ with the characterization of the prognostic significance in uterine endometrioid adenocarcinomas. Moreover, we determined the estrogen receptor expression in regard to several clinicopathological characteristics including surgical stage in endometrial adenocarcinomas of a well-characterized patient group $(23,24)$. In an analysis of 315 endometrial adenocarcinoma patients, the ratio of ER- $\alpha / E R-\beta$ might be a predictor of a shorter disease-free survival (22). However, in this analysis we have assessed the expression of both steroid receptors not as a ratio but as a combination of positive and negative expression $(14,18)$. Additionally, we have used endometrial adenocarcinoma specimens without other differentiation characteristics.

\section{Materials and methods}

Tissue samples. Pathological and surgical records of 214 patients who have been operated in the First Department of Obstetrics and Gynecology, Ludwig-Maximilians-University Munich between 1990 and 2002 were re-reviewed for this retrospective analysis. The evaluated patient group has been previously well characterized and an evaluation for several prognostic markers have been performed, including estrogen and progesterone receptors $(23,24)$. Women with other histological types than endometrioid adenocarcinomas were excluded from this study. Additionally, patients with mucinous and mixed adenocarcinomas (including squamous or villoglandular differentiation) were also excluded from this study.

All hematoxylin and eosin-stained slides were rereviewed to verify the diagnosis, histological grade, histological type, FIGO stage, lymphangiosis, adnexal or cervical involvement. Pathological stage and histological subtype were determined for each surgical specimen according to 1988 International Federation of Gynecology and Obstetrics (FIGO) criteria (8).

Patients with endometrial carcinoma received modified radical hysterectomy, salpingo-oophorectomy or selective pelvic lymphadenectomy, with or without para-aortic lymphadenectomy. Lymph node sampling or dissection was generally performed in patients having tumors with deep myometrial invasion and/or high-grade or aggressive histological features. Obesity, advanced age and excessive comorbidity were factors against full surgical staging.

Patient data were obtained from three sources: hospital tumor registry, automated database and chart review as previously described $(23,24)$. All cases of recurrence had radiographic evidence of disease or biopsy-proven progression of disease. Only the records of patients who died of disease were considered to be uncensored; the records of all patients who were alive at follow-up or who did not die of disease (or a related cause) were considered to be censored. Additionally, censored cases were also considered those cases where the exact cause of death was unknown but died within two years after the diagnosis of a metastatic lesion.
Immunohistochemistry. Immunohistochemistry was performed using a combination of microwave-oven heating and the standard streptavidin-biotin-peroxidase complex using the mouse-IgG-Vectastain Elite ABC kit (Vector Laboratories, Burlingame, CA, USA) as previously described $(23,25,26)$. Mouse monoclonal antibodies used for the experiments ER- $\alpha$ (1D5; mouse IgG1; 1:150 in dilution-medium; Immunotech Hamburg, Germany) and ER-ß (PPG5/10; mouse IgG2a; 1:50 in PBS; Serotec, Oxford, UK) as previously described $(23,25,26)$. For positive controls sections of human breast cancer tissue and normal colon were used, while human ileum served as negative control tissue as previously described (25).

Immunohistochemical evaluation. The intensity and distribution patterns of specific steroid receptor immunohistochemical staining reaction was evaluated by two blinded, independent observers, including a gynecological pathologist, using a semi-quantitative score as previously described (27) and used to assess the expression pattern of steroid receptors in human endometrium $(23,25,26)$. The IRS score was calculated by multiplication of optical staining intensity (graded as 0 , no; 1; weak; 2; moderate and 3; strong staining) and the percentage of positive stained cells $(0$, no staining; $1,<10 \%$ of the cells; $2 ; 11-50 \%$ of the cells; $3,51-80 \%$ of the cells; and $4,>81 \%$ of the cells). Sections were examined using a Leika (Tokyo, Japan) photomicroscope. Digital images were obtained with a digital camera system and were saved in a computer.

Statistical analysis. For the purposes of statistical survival analysis, steroid receptor expression in tumor samples, was considered to be elevated if $>10 \%$ positive staining was observed as previously suggested, which corresponds per definition to an immunohistochemical staining score (IRS) higher than two (23). For the evaluation of the ER- $\beta$ staining intensity the median for all tumor samples was used (median for ER- $\beta, 0)$. Increased/positive versus not increased/negative immunostaining in tumor samples was compared using the $\chi^{2}$ test and the exact Fisher's test where applicable.

The outcomes analyzed were progression-free survival, cause-specific survival and overall survival. Univariate analysis was performed with Kaplan-Meier life-table curves to estimate survival (28) and were compared using the logrank test. Prognostic models used multivariate Cox regression analysis for multivariate analyses of survival. The variables were entered in a forward stepwise manner (29). Significance of differences was assumed at $\mathrm{p} \leq 0.05$ was used (SPSS version 16.0; SPSS Inc., Chicago, IL).

\section{Results}

Clinicopathological characterization. The clinicopathological features of the endometrial carcinomas are summarized in Table I. The median patient's age at the time of diagnosis was 65.11 years (range, 35.49-87.89 years). One hundred and seventy-one $(79.91 \%)$ and $15(7.01 \%)$ patients were diagnosed in FIGO stage I and II respectively, while 21 (9.81\%) patients had FIGO stage III and 7 patients $(3.27 \%$ ) presented with metastatic disease (FIGO IV). Histological classification was performed according to the World Health Organization system 
Table I. Clinicopathological characteristics of the analyzed endometrioid adenocarcinomas.

\begin{tabular}{|c|c|}
\hline Paramater & $\begin{array}{l}\text { Endometrioid adenoca } \\
\qquad(\mathrm{n}=214)(\%)\end{array}$ \\
\hline \multicolumn{2}{|l|}{ Age (years) } \\
\hline$\leq 65$ & $107(50)$ \\
\hline$>65$ & $107(50)$ \\
\hline \multicolumn{2}{|l|}{ Grading } \\
\hline Grade 1 & $134(62.62)$ \\
\hline Grade 2 & $56(26.17)$ \\
\hline Grade 3 & $24(11.21)$ \\
\hline \multicolumn{2}{|l|}{ FIGO stage } \\
\hline FIGO I & $171(79.91)$ \\
\hline FIGO Ia & $29(13.55)$ \\
\hline FIGO Ib & 99 (46.26) \\
\hline FIGO Ic & $43(20.09)$ \\
\hline FIGO II & $15(7.01)$ \\
\hline FIGO 2a & $2(0.93)$ \\
\hline FIGO 2b & $13(6.07)$ \\
\hline FIGO III & $21(9.81)$ \\
\hline FIGO $3 \mathrm{a}$ & $9(4.21)$ \\
\hline FIGO 3b & $3(1.4)$ \\
\hline FIGO 3c & $9(4.21)$ \\
\hline FIGO IV & $7(3.27)$ \\
\hline \multicolumn{2}{|l|}{ Myometrial invasion } \\
\hline Only endometrial invasion & $34(15.89)$ \\
\hline$\leq 50 \%$ myometrium & $111(51.87)$ \\
\hline$>50 \%$ myometrium & $69(32.24)$ \\
\hline \multicolumn{2}{|l|}{ Cervical invasion } \\
\hline Negative & $191(89.25)$ \\
\hline Positive & $23(10.75)$ \\
\hline \multicolumn{2}{|l|}{ Ovarial invasion } \\
\hline Negative & $204(95.33)$ \\
\hline Positive & $10(4.67)$ \\
\hline \multicolumn{2}{|l|}{ LN status } \\
\hline Negative & $140(65.42)$ \\
\hline Positive & $11(5.14)$ \\
\hline Unknown & $63(29.44)$ \\
\hline \multicolumn{2}{|l|}{ Lymphangiosis } \\
\hline Negative & $197(92.06)$ \\
\hline Positive & $17(7.94)$ \\
\hline \multicolumn{2}{|l|}{ Adipositas } \\
\hline Negative & $137(64.02)$ \\
\hline Positive & $77(35.98)$ \\
\hline \multicolumn{2}{|l|}{ Diabetes } \\
\hline Negative & $187(87.38)$ \\
\hline Positive & $27(12.62)$ \\
\hline \multicolumn{2}{|l|}{ Hypertension } \\
\hline Negative & $126(58.88)$ \\
\hline Positive & 88 (41.12) \\
\hline \multicolumn{2}{|l|}{ Chemotherapy } \\
\hline Not performed & $208(97.2)$ \\
\hline Performed & $5(2.34)$ \\
\hline Denial & $1(0.47)$ \\
\hline
\end{tabular}

Table I. Continued.

\begin{tabular}{lc}
\hline Paramater & $\begin{array}{c}\text { Endometrioid adenocarcinoma } \\
(\mathrm{n}=214)(\%)\end{array}$ \\
\hline Radiotherapy & \\
Not performed & $132(61.68)$ \\
Performed & $76(35.51)$ \\
Denial & $6(2.8)$ \\
Anti-hormonal therapy & \\
Negative & $207(96.73)$ \\
Positive & $7(3.27)$ \\
\hline
\end{tabular}

in well-differentiated $(\mathrm{G} 1 ; \mathrm{n}=134)$, moderate differentiated (G2; n=56) and poor-differentiated (G3; n=24). Lymph node sampling or dissection was generally performed in patients having tumors with deep myometrial invasion and/or highgrade or aggressive histological features. Pelvic and/or paraaortic lymph node sampling was performed for 151 patients $(70.56 \%)$ while 11 patients $(5.14 \%)$ demonstrated lymph node metastasis. A low FIGO stage (FIGO Ia), obesity, advanced age and excessive comorbidity were factors against a full surgical staging in 63 patients $(29.44 \%)$. Obesity was observed in $77(35.98 \%)$ cases, while $88(41.2 \%)$ and $27(12.62 \%)$ patients presented with high blood pressure and diabetes respectively. Of the 214 patients, 76 patients $(35.51 \%)$ received a radiation therapy, while 7 patients $(3.27 \%)$ received an anti-hormone therapy. During the follow-up interval, tumor recurrence was observed in 29 patients $(13.6 \%)$, and 25 patients $(11.7 \%)$ died of disease. Sixty-two (29\%) died during the entire observation period until May 2009.

Endometrial carcinoma samples. Positive ER- $\alpha$ and ER- $\beta$ immunostaining was observed in 94 (43.9\%) and 29 (13.6\%) of 214 endometrial carcinoma samples respectively (Fig. 1a and $b$ ). ER- $\alpha$ expression in endometrial carcinoma samples demonstrated a significant association with grading $(\mathrm{p}=0.037$; 1 -sighted) (Table II). ER- $\beta$ could not be correlated with any of the assessed clinicopathological characteristics of the patients besides ovarian invasion ( $\mathrm{p}=0.032)$.

Eleven patients $(5.14 \%)$ demonstrated a positive, while 102 patients $(44.66 \%)$ showed a negative immunolabelling for both ER- $\alpha$ and ER- $\beta$ receptors (Table II). A positive immunohistochemical staining reaction for only one estrogen receptor was determined for $83(38.79 \%)$ and $18(8.41 \%)$ patients for ER- $\alpha$ and ER- $\beta$ expression respectively (Table II). This differential expression of both ER's could not be correlated with any of the assessed clinicopathological characcteristics of the patients besides ovarian invasion $(\mathrm{p}=0.038)$ (Table II).

Survival analysis. The median time to progression for the uncensored subgroup was 28.62 months (range, 0.03-168.95 months), whereas the median follow-up of censored patients was 100.13 months (range, 0.03-176.82 months). The median for the cause-associated death for the uncensored subgroup was 27.37 months (range, 3.15-130.39 months), whereas the median follow-up of censored patients was 96.32 months 
Table II. Univariate statistical analysis for positive estrogen receptor- $\alpha$ and estrogen receptor- $\beta$ according to various clinicopathological features.

\begin{tabular}{|c|c|c|c|c|c|c|c|c|c|}
\hline & & \multicolumn{2}{|c|}{ ER- $\alpha$} & \multicolumn{2}{|c|}{ ER- $\beta$} & \multicolumn{4}{|c|}{ ER- $\alpha /$ ER- $\beta$} \\
\hline & & Negative & Positive & Negative & Positive & ER- $\alpha+/$ ER- $\beta+$ & ER- $\alpha+/$ ER- $\beta-$ & ER- $\alpha$-/ER- $\beta+$ & ER- $\alpha-/ E R-\beta-$ \\
\hline \multicolumn{10}{|l|}{ Age (years) } \\
\hline$\leq 65$ & $107(50)$ & $62(57.94)$ & $45(42.06)$ & $92(85.98)$ & $15(14.02)$ & $5(4.67)$ & $40(37.38)$ & $10(9.35)$ & $52(48.60)$ \\
\hline$>65$ & $107(50)$ & $58(54.21)$ & $49(45.79)$ & $93(86.92)$ & $14(13.08)$ & $6(5.61)$ & 43 (40.19) & $8(7.48)$ & $50(46.73)$ \\
\hline$\chi^{2}$ & & & N.S. & & N.S. & & & & N.S. \\
\hline \multicolumn{10}{|l|}{ Grading } \\
\hline Grade $1+2$ & 190 (88.79) & $102(53.68)$ & $88(46.32)$ & 164 (86.32) & $26(13.68)$ & $11(5.79)$ & $77(40.53)$ & $15(7.89)$ & 87 (45.79) \\
\hline Grade 3 & $24(11.21)$ & $18(75)$ & $6(25)$ & $21(87.5)$ & $3(12.5)$ & $0(0)$ & $6(25)$ & $3(12.5)$ & $15(62.5)$ \\
\hline$\chi^{2}$ & & & $\begin{array}{c}0.037 \\
\text { (1-sighted) }\end{array}$ & & N.S. & & & & N.S. \\
\hline \multicolumn{10}{|l|}{ FIGO stage } \\
\hline FIGO I + II & $186(86.92)$ & $101(54.30)$ & $85(45.70)$ & $161(86.56)$ & $25(13.44)$ & $9(4.84)$ & $76(40.86)$ & $16(8.60)$ & $85(45.70)$ \\
\hline FIGO III + IV & $28(13.08)$ & $19(67.86)$ & $9(32.14)$ & $24(85.71)$ & $4(14.29)$ & $2(7.14)$ & $7(25)$ & $2(7.14)$ & $17(60.71)$ \\
\hline$\chi^{2}$ & & & N.S. & & N.S. & & & & N.S. \\
\hline \multicolumn{10}{|c|}{ Myometrial invasion } \\
\hline$<50 \%$ & $145(67.76)$ & $77(53.10)$ & $68(46.90)$ & $124(85.51)$ & $21(14.48)$ & $9(6.21)$ & $59(40.69)$ & $12(8.28)$ & $65(44.83)$ \\
\hline$>50 \%$ & $69(32.24)$ & $43(62.32)$ & $26(37.68)$ & $61(88.41)$ & $8(11.59)$ & $2(2.90)$ & $24(34.78)$ & $6(8.70)$ & $37(53.62)$ \\
\hline$\chi^{2}$ & & & N.S. & & N.S. & & & & N.S. \\
\hline \multicolumn{10}{|l|}{ Cervical invasion } \\
\hline Negative & $191(89.25)$ & $107(56.02)$ & $84(43.98)$ & $166(86.91)$ & $25(13.09)$ & $9(4.71)$ & $75(39.27)$ & $16(8.38)$ & $91(47.64)$ \\
\hline Positive & $23(10.75)$ & $13(56.52)$ & $10(43.48)$ & $19(82.61)$ & $4(17.39)$ & $2(8.70)$ & $8(34.78)$ & $2(8.70)$ & $11(47.83)$ \\
\hline$\chi^{2}$ & & & N.S. & & N.S. & & & & N.S. \\
\hline \multicolumn{10}{|l|}{ Ovarian invasion } \\
\hline Negative & 204 (95.33) & $113(55.39)$ & $91(44.61)$ & $179(87.75)$ & $25(12.25)$ & $9(4.41)$ & $82(40.20)$ & $16(7.84)$ & $97(47.55)$ \\
\hline Positive & $10(4.67)$ & $7(70)$ & $3(30)$ & $6(60)$ & $4(40)$ & $2(20)$ & $1(10)$ & $2(20)$ & $5(50)$ \\
\hline$\chi^{2}$ & & & N.S. & & 0.032 & & & & 0.038 \\
\hline \multicolumn{10}{|l|}{ LN status } \\
\hline Negative & $140(65.42)$ & $76(54.29)$ & $64(45.71)$ & $120(85.71)$ & $20(14.29)$ & $7(5)$ & $57(40.71)$ & $13(9.29)$ & $63(45)$ \\
\hline Positive & $11(5.14)$ & $8(72.73)$ & $3(27.27)$ & $10(90.91)$ & $1(9.09)$ & $1(9.09)$ & $2(18.18)$ & $0(0)$ & $8(72.73)$ \\
\hline Unknown & 63 (29.44) & $36(57.14)$ & $27(42.86)$ & $55(87.30)$ & $8(12.70)$ & $3(4.76)$ & $24(38.10)$ & $5(7.94)$ & $31(49.21)$ \\
\hline$\chi^{2}$ & & & N.S. & . & N.S. & & & & N.S. \\
\hline \multicolumn{10}{|l|}{ Lymphangiosis } \\
\hline Negative & 197 (92.06) & $110(55.84)$ & 87 (44.16) & $169(85.79)$ & $28(14.21)$ & $10(5.08)$ & 77 (39.09) & $18(9.14)$ & $92(46.70)$ \\
\hline Positive & $17(7.94)$ & $10(58.82)$ & 7 (41.18) & $16(94.12)$ & $1(5.88)$ & $1(5.88)$ & $6(35.29)$ & $0(0)$ & $10(58.82)$ \\
\hline$\chi^{2}$ & & & N.S. & & N.S. & & & & N.S. \\
\hline \multicolumn{10}{|l|}{ Adipositas } \\
\hline Negative & 137 (64.02) & $76(55.47)$ & $61(44.53)$ & $114(83.21)$ & $23(16.79)$ & $9(6.57)$ & $52(37.96)$ & $14(10.22)$ & $62(45.26)$ \\
\hline Positive & $77(35.98)$ & $44(57.14)$ & $33(42.86)$ & $71(92.21)$ & $6(7.79)$ & $2(2.60)$ & $31(40.26)$ & $4(5.19)$ & $40(51.95)$ \\
\hline$\chi^{2}$ & & & N.S. & & $\begin{array}{c}0.047 \\
\text { (1-sighted) }\end{array}$ & & & & N.S. \\
\hline \multicolumn{10}{|l|}{ Diabetes } \\
\hline Negative & 187 (87.38) & $104(55.61)$ & $83(44.39)$ & $162(86.63)$ & $25(13.37)$ & $9(4.81)$ & 74 (39.57) & $16(8.56)$ & $88(47.06)$ \\
\hline Positive & $27(12.62)$ & $16(59.26)$ & $11(40.74)$ & 23 (85.19) & $4(14.81)$ & $2(7.41)$ & $9(33.33)$ & $2(7.41)$ & $14(51.85)$ \\
\hline$\chi^{2}$ & & N.S. & & N.S. & & N.S. & & & \\
\hline \multicolumn{10}{|l|}{ Hypertension } \\
\hline Negative & $126(58.88)$ & $69(54.76)$ & $57(45.24)$ & 107 (84.92) & $19(15.08)$ & $8(6.35)$ & 49 (38.89) & $11(8.73)$ & $58(46.03)$ \\
\hline Positive & $88(41.12)$ & $51(57.95)$ & $37(42.05)$ & 78 (88.64) & $10(11.36)$ & $3(3.41)$ & 34 (38.64) & $7(7.95)$ & $44(50)$ \\
\hline$\chi^{2}$ & & & N.S. & & N.S. & & & & N.S. \\
\hline \multicolumn{10}{|l|}{ Radiotherapy } \\
\hline Not performed & $138(64.49)$ & $72(52.17)$ & $66(47.83)$ & $119(86.23)$ & 19 (13.77) & $8(5.80)$ & $58(42.03)$ & $11(7.97)$ & $61(44.20)$ \\
\hline Performed & $76(35.51)$ & $48(63.16)$ & $28(36.84)$ & $66(86.84)$ & $10(13.16)$ & $3(3.95)$ & $25(32.89)$ & $7(9.21)$ & $41(53.95)$ \\
\hline$\chi^{2}$ & & & N.S. & & N.S. & & & & N.S. \\
\hline
\end{tabular}

N.S., not significant. 

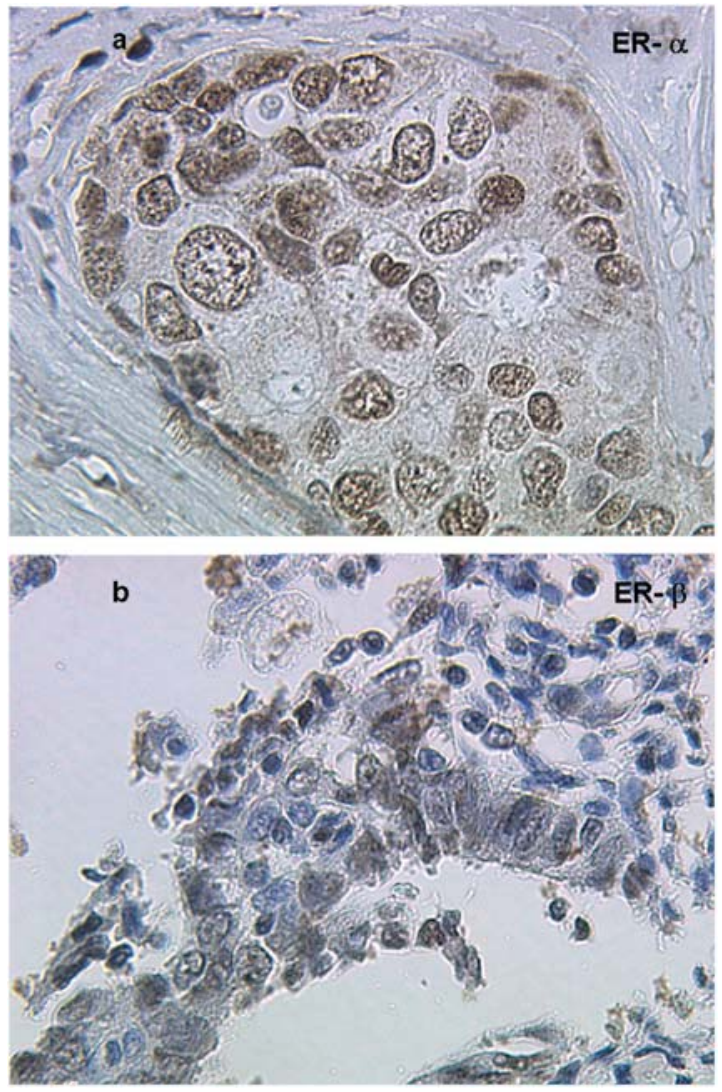

Figure 1. Expression of ER- $\alpha$ and ER- $\beta$ in human endometrioid adenocarcinoma. ER $\alpha$ shows moderate to strong immunohistochemical expression in endometrioid adenocarcinomas with a characteristic nuclear staining reaction $(\mathrm{a}, \mathrm{x} 400)$. In contrast, ER- $\beta$ demonstrates minimal $(\mathrm{b}, \mathrm{x} 400)$ to no immunoreactivity.

(range, 0.03-176.82 months). Other clinical parameters, including advanced surgical stage (stage I/II versus stage III/IV) and advanced histological grade (G3 versus G1 or G2), which are known prognostic factors of endometrial cancer, significantly affected the survival rates in our patients, demonstrating the validity of the patient group enrolled in this study $(23,24)$.

Univariate survival analysis revealed that patients with a ER- $\alpha$ had a significant better cause-specific survival compared with the patients with no expression (Fig. 2) ( $\mathrm{p}=0.016$, log-rank test). In contrast, ER- $\beta$ expression did not demonstrate any significant differences in progression-free survival, cause-specific survival and overall survival ( $p>0.05$ ) (Fig. 3).

Interestingly, ER- $\alpha$ and ER- $\beta$ did not demonstrate any significant survival benefit with regard to the FIGO stage with exception of FIGO IV patients $(\mathrm{p}=0.018$ and $\mathrm{p}=0.025$ respectively, log-rank test) (Table III). By analyzing the combined ER- $\alpha /$ ER- $\beta$ expression, we could demonstrate a significant cause-specific survival benefit of patients expressing ER- $\alpha$ compared to patients being negative for both receptors (Fig. 4 and Table IV).

Prognostic factors were also analyzed by the multivariate Cox proportional-hazard model. For the stepwise logistic regression models, we included the following variables: age, FIGO stage, tumor grading, myometrial invasion, cervical invasion, ovarial invasion, lymph node status, lymphangiosis, ER- $\alpha$, ER- $\beta$ and ER- $\alpha / E R-\beta$. Forward stepwise elimination
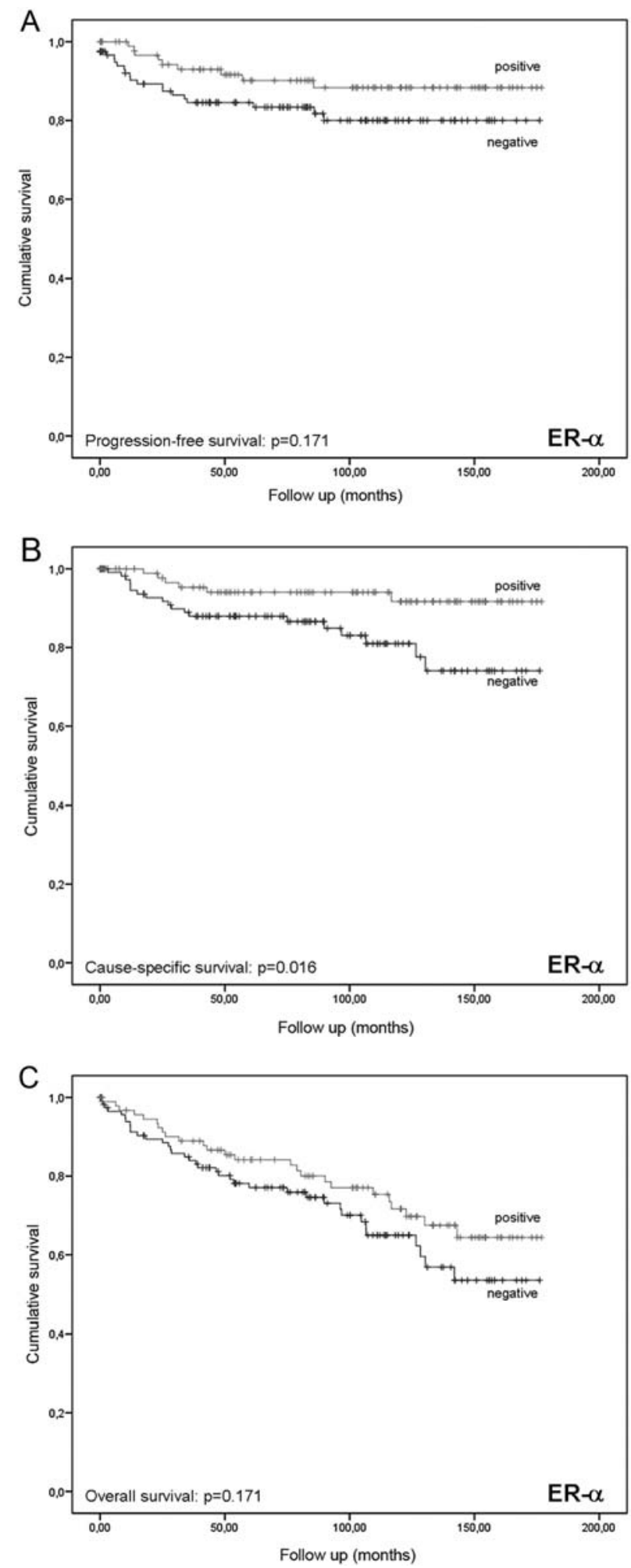

Figure 2. Kaplan-Meier curves of clinical outcome regarding ER- $\alpha$ expression for progression-free survival (A), cause-specific survival (B) and overall survival (C).

according to Cox regression results led to a model containing three independent terms that were predictive of progressionfree survival: WHO grading $(\mathrm{p}=0.017)$, FIGO stage $(\mathrm{p}<0.001)$ and cervical invasion $(\mathrm{p}=0.009)$ (Table V). Four independent prognostic factors for cause-specific survival were identified: FIGO stage $(\mathrm{p}<0.05)$, cervical invasion $(\mathrm{p}=0.004)$, myometrial 

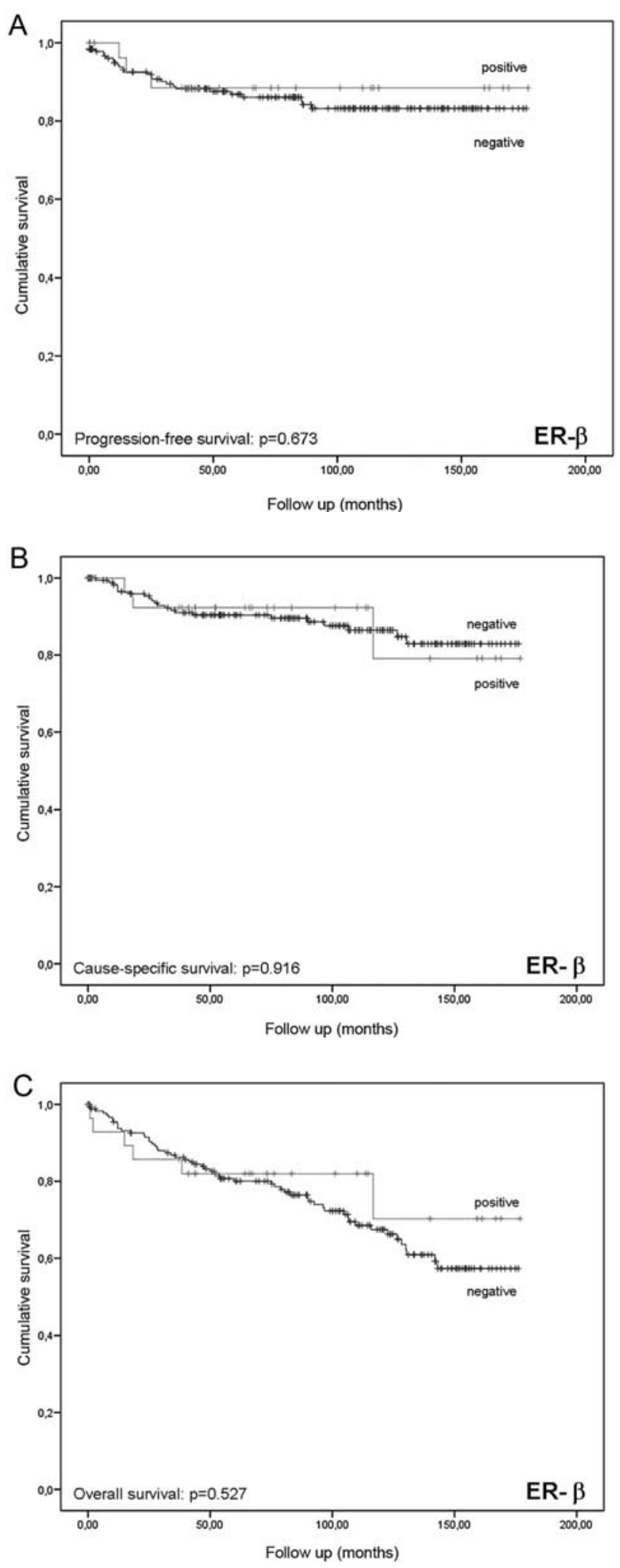

Figure 3. Kaplan-Meier curves of clinical outcome regarding ER-ß expression for progression-free survival (A), cause-specific survival (B) and overall survival (C).

invasion $(\mathrm{p}=0.027)$ and lymph node involvement $(\mathrm{p}=0.012)$. The overall survival was influenced by age $(\mathrm{p}<0.001)$, tumor grade $(\mathrm{p}=0.012)$, FIGO stage $(\mathrm{p}=0.006)$, cervical invasion $(\mathrm{p}<0.001)$ and lymph node involvement $(\mathrm{p}=0.001)($ Table $\mathrm{V})$.
Table III. Univariate statistical analysis (log-rank test) for positive estrogen receptor- $\alpha$ and estrogen receptor- $\beta$ according to surgical stage (FIGO).

\begin{tabular}{llllll}
\hline & \multicolumn{2}{c}{ ER- $\alpha$} & & \multicolumn{2}{c}{ ER- $\beta$} \\
\cline { 2 - 3 } \cline { 5 - 6 } & \multicolumn{1}{c}{$\chi^{2}$} & Significance & & $\chi^{2}$ & Significance \\
\hline Progression-free survival & & & & \\
$\quad$ FIGO I & 0.0092 & 0.924 & & 0.0455 & 0.831 \\
FIGO II & 0.3690 & 0.544 & & 1.0708 & 0.301 \\
FIGO III & 2.0352 & 0.154 & & 0.0547 & 0.815 \\
FIGO IV & 1.8 & 0.180 & & 0.75 & 0.386 \\
Cause-specific survival & & & & \\
FIGO I & 0.0092 & 0.924 & & 0.1889 & 0.664 \\
FIGO II & 0.369 & 0.544 & & 1.0709 & 0.301 \\
FIGO III & 2.035 & 0.154 & & 0.4106 & 0.521 \\
FIGO IV & 1.8 & 0.180 & & \\
Overall survival & & & & \\
FIGO I & 0.986 & 0.321 & & 0.1103 & 0.740 \\
FIGO II & 0.1356 & 0.713 & & 2.5731 & 0.109 \\
FIGO III & 0.877 & 0.350 & 0.0738 & 0.786 \\
FIGO IV & 5.628 & $\mathbf{0 . 0 1 8}$ & 5 & $\mathbf{0 . 0 2 5}$ \\
\hline
\end{tabular}

\section{Discussion}

Endometrial cancer is the most frequent gynecologic malignancy in the Western world with several prognostic factors such as histological type, histological grade, surgical stage, pelvic lymph node involvement and myometrial invasion being established (1-6). Although $>50 \%$ of patients with endometrial carcinomas are diagnosed with FIGO stage I, as many as $20 \%$ die as a result of their disease (30). This unusual situation might reflect that the current used diagnostic technology is quite insufficient to identify endometrial cancer patients with poor prognosis. Therefore, immunohistochemistry of different specific markers might be an interesting alternative to select high risk patients leading to a more patient specific risk profile and treatment $(22,23,31,32)$.

Steroid receptor status is thought to constitute independent prognostic factors in endometrial cancer patients $(3,33,34)$. Therefore, the National Cancer Institute of the USA has recommended an incorporation of these parameters in the evaluation of endometrial cancer patients with stage I and II. However, the usefulness of determining steroid receptors in human endometrial cancer patients is still controversially discussed $(23,24)$.

The ER- $\alpha$ status is believed to provide prognostic information independent of tumor stage and grade in women with endometrial carcinoma $(3,15,16)$. Additionally, clinical data in relation to the prevalence of steroid receptor isoforms ER- $\alpha$ and ER- $\beta$ are rare $(20,22,23)$. However, ER- $\beta$ might also play an important role in endometrial carcinogenesis, probably as a result to the different binding characteristics $(17,35,36)$. Interestingly, the loss of ER- $\beta$ expression in cancer cells might be a characteristic step in tumor cell dedifferentiation (13). Additionally, variant proteins originating 

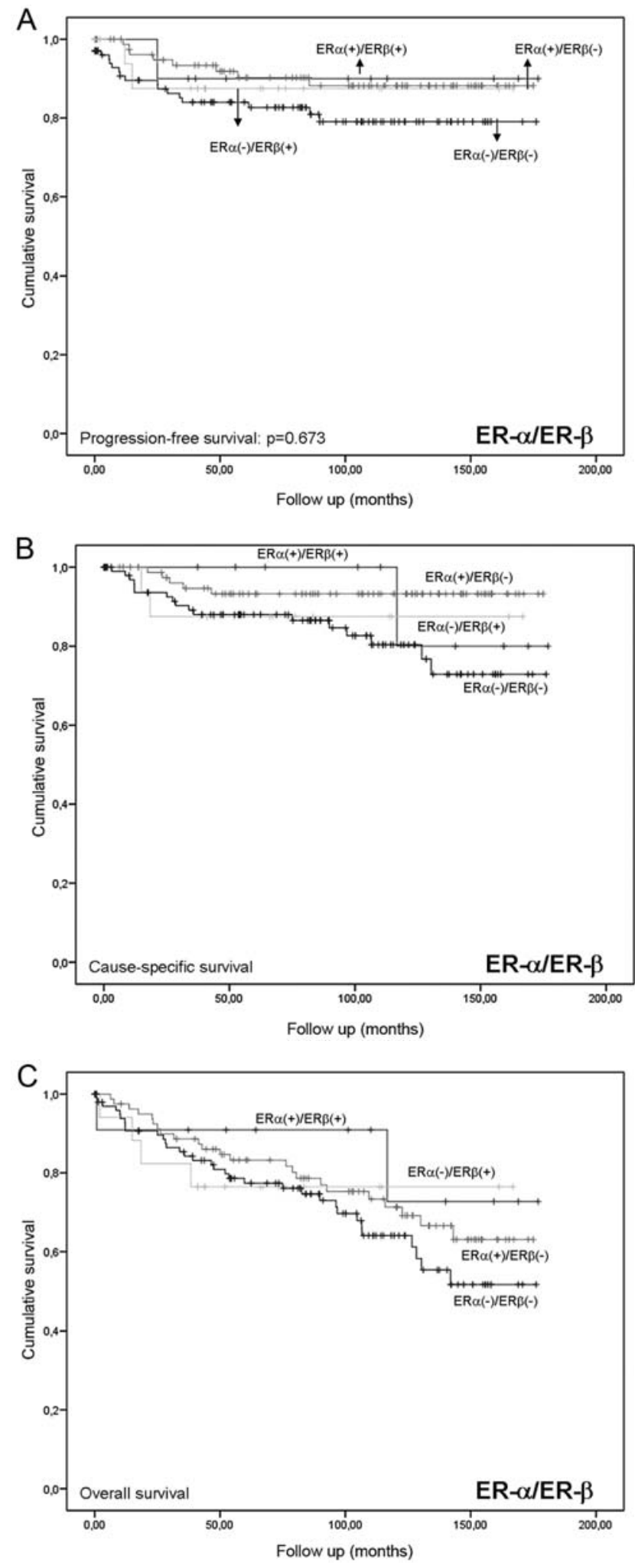

Figure 4. Kaplan-Meier curves of clinical outcome regarding the combination of ER- $\alpha$ and ER- $\beta$ expression for progression-free survival (A), cause-specific survival (B) and overall survival (C). For statistical data see Table IV.

from transcriptional splicing errors have been described for ER- $\alpha$ and ER- $\beta$, being able to activate the transcription of ERdependent genes without the presence of steroid hormones $(37,38)$, leading to a potentially uncontrolled proliferation (37-39). Therefore, the combination of ER- $\alpha$ and ER- $\beta$ expression might be of essential importance in assessing the risk profile of each patient with endometrial cancer.

In this sub-analysis of endometrioid adenocarcinomas, ER- $\alpha$ was associated with histological differentiation, while ER- $\beta$ demonstrated an association with ovarial invasion. Interestingly, the combined ER- $\alpha$ and ER- $\beta$ positivity demonstrated an association with ovarial invasion. It has been demonstrated that ER- $\alpha$ mRNA and protein expression are decreasing in stages from normal or grade 1 to grade 3 tumor lesions, whereas ER- $\beta$ expression is not altered, suggesting a shift to a decreased ER- $\alpha / E R-\beta$ ratio $(40,41)$. Moreover, the ratio of ER- $\alpha /$ ER- $\beta$ differed between normal and malignant tissues, whereas a higher ER- $\alpha / E R-\alpha$ ratio was observed in breast and endometrial carcinoma $(13,14,18)$. Moreover, the disrupted ER- $\alpha / E R-\beta$ relation is associated with ovarial invasion, implicating these steroid receptors with malignant transformation and the metastatic potential of endometrioid adenocarcinomas. This seems to be confirmed by the fact that ER- $\alpha$ and ER- $\beta$ only demonstrated a significant survival benefit in patients with metastatic stage (FIGO IV). Interestingly, the ER- $\beta / E R-\alpha$ mRNA ratio was high in advanced invasive carcinoma. Additionally, Western blot analysis demonstrated that ER- $\beta$ was highly expressed in comparison with ER- $\alpha$ in endometrial cancer with severe myometrial invasion, suggesting that ER- $\beta$ is important in the progression of myometrial invasion (19).

With regard to survival, we showed that ER- $\alpha$ is a significant prognostic marker regarding cause-specific survival in univariate analysis. In contrast, ER- $\beta$ expression did not demonstrate any significant differences in progression-free survival, cause-specific survival and overall survival. By analyzing the combined ER- $\alpha /$ ER- $\beta$ expression, we could demonstrate a significant cause-specific survival benefit of patients expressing ER- $\alpha$ compared to patients being negative for both receptors. These data emphasize that the primary estrogen action is mediated through the ER- $\alpha$ rather than ER- $\beta$ receptor. However, we determined that ER- $\alpha$ and ER- $\beta$ receptor status did not constitute an independent prognostic factor confirming previous results $(23,31,42)$.

Previously, we demonstrated in a large series of 293 analyzed cases, that the lack of ER- $\alpha$ in endometrial cancer patients was associated with poor differentiation and constitutes an important survival factor (23). Moreover, in an analysis of 315 endometrial adenocarcinoma patients, the ratio of ER- $\alpha / E R-\beta$ might be a predictor of a shorter disease-free survival (22). Therefore, the intact synchronized expression of ER- $\beta$ interacting with ER- $\alpha$ might be disrupted in malignant endometrium (20), playing an important role in endometrial carcinogenesis. Therefore ER- $\beta$ is only useful if it is evaluated with the ER- $\alpha$ expression, since the ratio of the two steroid receptors is probably more useful than evaluating each receptor separately.

Summarizing, an expression of both estrogen receptors (ER- $\alpha$ and ER- $\beta$ ) in malignant endometrioid adenocarcinomas was demonstrated, whereas ER- $\alpha$ was associated with histological differentiation, while ER- $\beta$ demonstrated an association with ovarial invasion. The loss of receptor positivity for ER- $\alpha$ resulted in a poorer cause-specific survival in endometrial cancer patients, while ER- $\beta$ did not affect survival. Interestingly, patients with metastasis who expressed ER- $\alpha$ or 
Table IV. Univariate statistical analysis (log-rank test) for the combination of ER- $\alpha$ and ER- $\beta$.

\begin{tabular}{|c|c|c|c|c|c|c|c|c|}
\hline \multirow[b]{2}{*}{ ER- $\alpha /$ ER- $\beta$} & \multicolumn{2}{|c|}{$\operatorname{ER}-\alpha(+) / \operatorname{ER}-\beta(+)$} & \multicolumn{2}{|c|}{ ER- $\alpha(+) / E R-\beta(-)$} & \multicolumn{2}{|c|}{ ER- $\alpha(-) / E R-\beta(+)$} & \multicolumn{2}{|c|}{ ER- $\alpha(-) / E R-\beta(-)$} \\
\hline & $\chi^{2}$ & Significance & $\chi^{2}$ & Significance & $\chi^{2}$ & Significance & $\chi^{2}$ & Significance \\
\hline \multicolumn{9}{|c|}{ Progression-free survival } \\
\hline ER- $\alpha(+) / E R-\beta(+)$ & & & 0.0009 & 0.976 & 0.0563 & 0.813 & 0.5212 & 0.470 \\
\hline ER- $\alpha(+) / E R-\beta(-)$ & 0.0009 & 0.975 & & & 0.1716 & 0.679 & 2.7500 & 0.097 \\
\hline ER- $\alpha(-) / E R-\beta(+)$ & 0.0562 & 0.812 & 0.1716 & 0.679 & & & 0.3152 & 0.575 \\
\hline ER- $\alpha(-) / E R-\beta(-)$ & 0.5211 & 0.470 & 2.7499 & 0.097 & 0.3152 & 0.575 & & \\
\hline \multicolumn{9}{|l|}{ Cause-specific survival } \\
\hline ER- $\alpha(+) / E R-\beta(+)$ & & & 0.1195 & 0.730 & 0.3656 & 0.546 & 0.6883 & 0.407 \\
\hline ER- $\alpha(+) / E R-\beta(-)$ & 0.1195 & 0.730 & & & 0.766 & 0.381 & 5.658 & 0.017 \\
\hline ER- $\alpha(-) / E R-\beta(+)$ & 0.3656 & 0.545 & 0.7661 & 0.381 & & & 0.1006 & 0.751 \\
\hline ER- $\alpha(-) / E R-\beta(-)$ & 0.6883 & 0.407 & 5.6575 & 0.017 & 0.1006 & 0.751 & & \\
\hline \multicolumn{9}{|l|}{ Overall survival } \\
\hline ER- $\alpha(+) / E R-\beta(+)$ & & & 0.3922 & 0.531 & 0.3070 & 0.580 & 1.2704 & 0.260 \\
\hline ER- $\alpha(+) / E R-\beta(-)$ & 0.3923 & 0.531 & & & 0.0782 & 0.780 & 1.4380 & 0.230 \\
\hline ER- $\alpha(-) / E R-\beta(+)$ & 0.3070 & 0.580 & 0.0782 & 0.780 & & & 0.1086 & 0.741 \\
\hline ER- $\alpha(-) / E R-\beta(-)$ & 1.2703 & 0.260 & 1.4380 & 0.230 & 0.1086 & 0.742 & & \\
\hline
\end{tabular}

Table V. Hazard ratios by multivariate Cox regression analysis.

\begin{tabular}{|c|c|c|c|c|c|c|c|c|c|}
\hline & \multicolumn{3}{|c|}{ Progression-free survival } & \multicolumn{3}{|c|}{ Cause-specific survival } & \multicolumn{3}{|c|}{ Overall survival } \\
\hline & $\mathrm{RR}$ & CI $(5-95 \%)$ & P-value & $\mathrm{RR}$ & CI $(5-95 \%)$ & P-value & $\mathrm{RR}$ & CI $(5-95 \%)$ & P-value \\
\hline Age ( $>65$ years) & & & & & & & 3.85 & $2.049-7.234$ & $<0.001$ \\
\hline $\begin{array}{l}\text { WHO grade } \\
\text { (G1/G2 vs. G3) }\end{array}$ & 3 & $1.215-7.408$ & 0.017 & & & & 2.274 & $1.202-4.301$ & 0.012 \\
\hline $\begin{array}{l}\text { FIGO stage } \\
\text { (I/II vs. III/IV) }\end{array}$ & 5.629 & $2.49-12.727$ & $<0.001$ & 3.21 & $1.249-8.25$ & 0.015 & 2.459 & $1.287-4.699$ & 0.006 \\
\hline $\begin{array}{l}\text { Cervical invasion } \\
\text { (positive vs. negative) }\end{array}$ & 3.139 & $1.325-7.438$ & 0.009 & 3.866 & $1.525-9.798$ & 0.004 & 3.561 & $1.808-7.016$ & $<0.001$ \\
\hline $\begin{array}{l}\text { Myometrial invasion } \\
(>50 \% \text { vs. }<50 \%)\end{array}$ & & & & 2.961 & $1.131-7.753$ & 0.027 & & & \\
\hline $\begin{array}{l}\text { LN status } \\
\text { (positive vs. negative) }\end{array}$ & & & & 1.753 & $1.129-2.721$ & 0.012 & 1.597 & $1.215-2.101$ & 0.001 \\
\hline
\end{tabular}

ER- $\beta$ had a better survival outcome than estrogen receptor negative patients. When tumor samples of affected patients expressed ER- $\alpha$, they had a better cause-specific survival compared to negative findings regarding both estrogen receptors. However, ER- $\alpha$ and ER- $\beta$ were not independent factors with survival in endometrial adenocarcinoma patients. Therefore, the analysis of both estrogen receptors might be used as a marker to identify high-risk patients only in a subset of patients with endometrioid adenocarcinoma.

\section{Acknowledgements}

We would like to thank Dr N. Shabani, Mrs. C. Kuhn, Mrs. S. Kunze, Mrs. Schulze, Dr D. Mayr, Dr D. Dian, Dr A.
Gingelmaier, Dr C. Schindlbeck, Professor F. Willgeroth, Professor H. Sommer, Dr U. Jeschke, Professor K. Friese, Professor D. Hölzel and Mr. M. Schmidt for their precious help in conducting the primary analysis of steroid receptor expression in endometrial cancer patients. This study was partially supported by the FöFoLe program of the LudwigMaximilians-University Munich (297/03), the Friedrich-BaurInstitute and the Weigland Stipendium Program of the Ludwig-Maximilians-University Munich (to I. Mylonas).

\section{References}

1. Amant F, Moerman P, Neven P, Timmerman D, Van Limbergen E and Vergote I: Endometrial cancer. Lancet 9484: 491-505, 2005. 
2. Rose PG: Endometrial carcinoma. N Engl J Med 9: 640-649, 1996.

3. Creasman WT: Prognostic significance of hormone receptors in endometrial cancer. Cancer 4 (Suppl): 1467-1470, 1993.

4. Morrow CP, Bundy BN, Kurman RJ, Creasman WT, Heller P, Homesley HD and Graham JE: Relationship between surgicalpathological risk factors and outcome in clinical stage I and II carcinoma of the endometrium: a Gynecologic Oncology Group study. Gynecol Oncol 1: 55-65, 1991.

5. Abeler VM and Kjorstad KE: Endometrial adenocarcinoma in Norway. A study of a total population. Cancer 12: 3093-3103, 1991.

6. Prat J: Prognostic parameters of endometrial carcinoma. Hum Pathol 6: 649-662, 2004.

7. Gloeckler Ries LA, Reichman ME, Lewis DR, Hankey BF and Edwards BK: Cancer survival and incidence from the Surveillance, Epidemiology, and End Results (SEER) program. Oncologist 6: 541-552, 2003.

8. FIGO stages (announcements). Gynecol Oncol 125-127, 1989.

9. Deligdisch L and Holinka CF: Endometrial carcinoma: two diseases? Cancer Detect Prev 3-4: 237-246, 1987.

10. Bokhman JV: Two pathogenetic types of endometrial carcinoma. Gynecol Oncol 1: 10-17, 1983.

11. Kuiper GG, Shughrue PJ, Merchenthaler I and Gustafsson JA: The estrogen receptor beta subtype: a novel mediator of estrogen action in neuroendocrine systems. Front Neuroendocrinol 4: 253-286, 1998.

12. Kuiper GG and Gustafsson JA: The novel estrogen receptorbeta subtype: potential role in the cell- and promoter-specific actions of estrogens and anti-estrogens. FEBS Lett 1: 87-90, 1997.

13. Bardin A, Boulle N, Lazennec G, Vignon F and Pujol P: Loss of ERbeta expression as a common step in estrogen-dependent tumor progression. Endocr Relat Cancer 3: 537-551, 2004.

14. Utsunomiya H, Suzuki T, Harada N, Ito K, Matsuzaki S, Konno R, Sato S, Yajima A and Sasano H: Analysis of estrogen receptor alpha and beta in endometrial carcinomas: correlation with ER beta and clinicopathologic findings in 45 cases. Int J Gynecol Pathol 4: 335-341, 2000.

15. Chambers JT, MacLusky N, Eisenfield A, Kohorn EI, Lawrence R and Schwartz PE: Estrogen and progestin receptor levels as prognosticators for survival in endometrial cancer. Gynecol Oncol 1: 65-81, 1988.

16. Pertschuk LP, Masood S, Simone J, Feldman JG, Fruchter RG, Axiotis CA and Greene GL: Estrogen receptor immunocytochemistry in endometrial carcinoma: a prognostic marker for survival. Gynecol Oncol 1: 28-33, 1996.

17. Weihua Z, Saji S, Makinen S, Cheng G, Jensen EV, Warner M and Gustafsson JA: Estrogen receptor (ER) beta, a modulator of ERalpha in the uterus. Proc Natl Acad Sci USA 11: 5936-5941, 2000.

18. Sasano H, Suzuki T, Matsuzaki Y, Fukaya T, Endoh M, Nagura $\mathrm{H}$ and Kimura M: Messenger ribonucleic acid in situ hybridization analysis of estrogen receptors alpha and beta in human breast carcinoma. J Clin Endocrinol Metab 2: 781-785, 1999.

19. Takama F, Kanuma T, Wang D, Kagami I and Mizunuma $\mathrm{H}$ : Oestrogen receptor beta expression and depth of myometrial invasion in human endometrial cancer. Br J Cancer 4: 545-549, 2001.

20. Fujimoto J, Sakaguchi H, Aoki I, Toyoki H and Tamaya T: Clinical implications of the expression of estrogen receptoralpha and -beta in primary and metastatic lesions of uterine endometrial cancers. Oncology 3: 269-277, 2002.

21. Mylonas I, Makovitzky J, Friese K and Jeschke U: Immunohistochemical labelling of steroid receptors in normal and malignant human endometrium. Acta Histochem 4: 349-359, 2009.

22. Jongen V, Briet J, De Jong R, ten Hoor K, Boezen M, van der Zee A, Nijman $\mathrm{H}$ and Hollema $\mathrm{H}$ : Expression of estrogen receptor-alpha and -beta and progesterone receptor-A and -B in a large cohort of patients with endometrioid endometrial cancer. Gynecol Oncol 3: 537-542, 2009.

23. Shabani N, Kuhn C, Kunze S, Schulze S, Mayr D, Dian D, Gingelmaier A, Schindlbeck C, Willgeroth F, Sommer H, Jeschke U, Friese K and Mylonas I: Prognostic significance of oestrogen receptor alpha (ERalpha) and beta (ERbeta), progesterone receptor A (PR-A) and B (PR-B) in endometrial carcinomas. Eur J Cancer 16: 2434-2444, 2007.
24. Mylonas I, Worbs S, Shabani N, Kuhn C, Kunze S, Schulze S, Dian D, Gingelmaier A, Schindlbeck C, Bruning A, Sommer H, Jeschke $\mathrm{U}$ and Friese $\mathrm{K}$ : Inhibin-alpha subunit is an independent prognostic parameter in human endometrial carcinomas: analysis of inhibin/activin-alpha, -betaA and -betaB subunits in 302 cases. Eur J Cancer 7: 1304-1314, 2009.

25. Mylonas I, Jeschke U, Shabani N, Kuhn C, Kunze S, Dian D, Friedl C, Kupka MS and Friese K: Steroid receptors ERalpha, ERbeta, PR-A and PR-B are differentially expressed in normal and atrophic human endometrium. Histol Histopathol 2: 169-176, 2007.

26. Mylonas I, Jeschke U, Shabani N, Kuhn C, Kriegel S, Kupka MS and Friese K: Normal and malignant human endometrium express immunohistochemically estrogen receptor alpha (ER-alpha), estrogen receptor beta (ER-beta) and progesterone receptor (PR). Anticancer Res 3A: 1679-1686, 2005.

27. Remmele W and Stegner HE: Vorschlag zur einheitlichen Definierung eines immunreaktiven Score (IRS) für den immunhistochemischen Östrogenrezeptornachweis (ER-ICA) im Mammakarzinomgewebe. Pathologe 8: 138-140, 1987.

28. Kaplan EL and Meier P: Non-parametric estimation from incomplete observations. J Am Stat Assoc 53: 457-481, 1958.

29. Cox DR: Regression models and life tables. J R Stat Soc B 34: 187-220, 1972

30. Jereczek-Fossa B, Badzio A and Jassem J: Surgery followed by radiotherapy in endometrial cancer: analysis of survival and patterns of failure. Int J Gynecol Cancer 4: 285-294, 1999.

31. Jeon YT, Park IA, Kim YB, Kim JW, Park NH, Kang SB, Lee HP and Song YS: Steroid receptor expressions in endometrial cancer: clinical significance and epidemiological implication. Cancer Lett 2: 198-204, 2006.

32. Oreskovic S, Babic D, Kalafatic D, Barisic D and BeketicOreskovic L: A significance of immunohistochemical determination of steroid receptors, cell proliferation factor Ki-67 and protein p53 in endometrial carcinoma. Gynecol Oncol 1: $34-40,2004$.

33. Kadar N, Malfetano JH and Homesley HD: Steroid receptor concentrations in endometrial carcinoma: effect on survival in surgically staged patients. Gynecol Oncol 3: 281-286, 1993.

34. Nyholm HC, Christensen IJ and Nielsen AL: Progesterone receptor levels independently predict survival in endometrial adenocarcinoma. Gynecol Oncol 3: 347-351, 1995.

35. Kuiper GG, Carlsson B, Grandien K, Enmark E, Haggblad J, Nilsson S and Gustafsson JA: Comparison of the ligand binding specificity and transcript tissue distribution of estrogen receptors alpha and beta. Endocrinology 3: 863-870, 1997.

36. Lecce G, Meduri G, Ancelin M, Bergeron C and PerrotApplanat M: Presence of estrogen receptor beta in the human endometrium through the cycle: expression in glandular, stromal, and vascular cells. J Clin Endocrinol Metab 3: 1379-1386, 2001.

37. Bryant W, Snowhite AE, Rice LW and Shupnik MA: The estrogen receptor (ER)alpha variant Delta5 exhibits dominant positive activity on ER-regulated promoters in endometrial carcinoma cells. Endocrinology 2: 751-759, 2005.

38. Herynk MH and Fuqua SA: Estrogen receptor mutations in human disease. Endocr Rev 6: 869-898, 2004.

39. Horvath G, Leser G, Hahlin M and Henriksson M: Exon deletions and variants of human estrogen receptor mRNA in endometrial hyperplasia and adenocarcinoma. Int J Gynecol Cancer 2: 128-136, 2000

40. Jazaeri AA, Nunes KJ, Dalton MS, Xu M, Shupnik MA and Rice LW: Well-differentiated endometrial adenocarcinomas and poorly differentiated mixed mullerian tumors have altered ER and PR isoform expression. Oncogene 47: 6965-6969, 2001.

41. Saegusa M and Okayasu I: Changes in expression of estrogen receptors alpha and beta in relation to progesterone receptor and $\mathrm{pS} 2$ status in normal and malignant endometrium. Jpn J Cancer Res 5: 510-518, 2000.

42. Sivridis E and Giatromanolaki A: Prognostic aspects on endometrial hyperplasia and neoplasia. Virchows Arch 2: 118-126, 2001. 